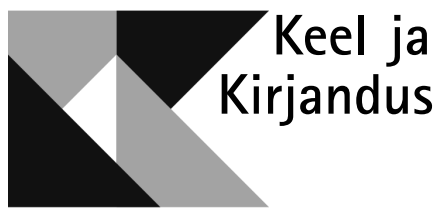

\title{
FERDINANDI MANTLIPÄRIJAD
}

\section{Saatesõna}

TÕNU TENDER

$\mathrm{T}$ ähtsaim eesti keele auhind - teenete eest eesti keele uurimisel, korraldamisel, õpetamisel, propageerimisel või kasutamisel - kannab väljapaistva keeleteadlase Ferdinand Johann Wiedemanni (1805-1887) nime. ${ }^{1}$ Keeleauhinna algatamise mõttele tulid 1988. aasta sügisel Irma ja Jüri Sild. Esimene keeleauhind anti üle 1989. aastal. Esialgu andis auhinda välja Energia kolhoos, Nõukogude korra ja kolhooside lõppemise järel rahastasid auhinna väljaandmist Jüri Sild (kolhoosi endine esimees), seejärel Väike-Maarja vald ja Eesti Keele Sihtasutus ning eraalgatusliku keeleauhinna paaril viimasel korral Haridus- ja Teadusministeerium. (Põhjalikumalt vt Ross 2005, 2008, 2013.) Alates 2004. aastast on auhind riiklik.

Kuidas ja miks sai keeleauhind just akadeemik Ferdinand Johann Wiedemanni nime? Sellele küsimusele ei ole selget vastust. Perekond Sildki ei tea täpselt või ei mäleta enam seda: „Kindlat vastust ei ole, kuid Wiedemanni nime sai keeleauhind kohe algul. Ühes vestluses mainis Rudolf Rimmel, ${ }^{2}$ et Wiedemann on käinud ka Väike-Maarjas.” (Sild, Sild 2013: 15)

${ }^{1}$ Akadeemik Huno Rätsep on kirjutanud: „Ma ei tea 19. sajandist ega varasemast ajast ühtki keeleteadlast, kes oleks nii palju eesti keele uurimisel ja tema ainestiku talletamisel korda saatnud kui akadeemik Ferdinand Johann Wiedemann. Kahekümnendast sajandist võime tema kõrvale seada üksnes Andrus Saareste, Johannes Aaviku ja Johannes Voldemar Veski." (Rätsep 2008: 27)

${ }^{2}$ Kirjanik ja ajakirjanik Rudolf Rimmel (1937-2003) oli auhinna saamisloos - selle asutamisel ja tutvustamisel - üks võtmeisikuid. Rimmeli abikaasa Malle on Jüri Silla õde (Ross 2005: 11, 2008: 19). 
1989. aasta veebruaris polnud asutataval keeleauhinnal veel nime: Rudolf Rimmel teatas 22. veebruaril 1989 Jüri Sillale adresseeritud kirjas, et ta kõneles Keele ja Kirjanduse Instituudi direktori kt Joel Sangaga „Energia” võimalikust keeleauhinnast" (siin ja edaspidi minu sõrendus - T. T.). Rimmel jätkab oma kirja: „Kuigi ülevaatlik, oli jutt siiski suhteliselt põgus ja saame uuesti kokku järgmisel teisipäeval, s.o. kuu viimasel päeval, kui Kirjanike Liidus toimub suurem kohtumine ideoloogiasekretäri Mikk Titmaga" (Ross 2013: 36-37). Kuid 17. märtsil 1989 kirjutas Rimmel J. Sillale, et auhind on Wiedemanni-nimeline: „Jõudu, esimees! Saadan sulle tutvumiseks Wiedemanninimelise (nii me otsustasime ta ristida) keeleauhinna põhikirja või -määruse esialgse või ka lõpliku variandi [---].” (Ross 2013: 37)

Kellega koos Rimmel auhinna Wiedemanni-nimeliseks ristis või kellelt inspiratsiooni sai? Kas neilt, kes 16. märtsil 1989. aastal auhinna põhikirja koostada aitasid, s.o Mart Remmelilt, Paul-Eerik Rummolt, Joel Sangalt ja Mart Susilt (Ross 2005: 13)? Auhinna sünnilugu ja kulgu uurinud Eevi Ross on siinkirjutajale 14. novembril 2018. aastal vestluses öelnud, et tagantjärele ei ole seda võimalik enam kindlaks teha. Võime ainult oletada ning fantaseerida.

Võimalik, et keeleauhinnale soovitas nime akadeemik Paul Ariste. Viimane pidas Wiedemanni väljapaistvaks keeleteadlaseks ja oli muuhulgas koostanud ülevaatliku raamatukese „Ferdinand Johann Wiedemann” (1973). Jüri Viikberg, Paul Ariste kunagine üliõpilane, on maininud, et Ariste võrdles ennast mõnikord lõbusamalt, mõnikord tõsisemalt Wiedemanniga, pidades end ehk isegi tema taaskehastuseks sajandilise rütmiga: Wiedemann oli sündinud 1805. aastal, Ariste 1905. aastal; mõlemad olid käinud ühes koolis - Gustav Adolfi Gümnaasiumis; esimene sai akadeemikuks (kirjavahetajaliikmeks) 1854, teine 1954 jne. Paul Ariste oli toona elus ning võis auhinnale nime soovitada.

Pea 30 aastat pärast keeleauhinna asutamist uuris siinkirjutaja Joel Sangalt, kas ta mäletab veel asutatavale keeleauhinnale nime otsimist. Sang vastas (26. X 2018) lakooniliselt: „Ei mäleta sellest ajast suurt midagi. Minu juurde tuli selle jutuga, et tuleks asutada Wiedemanni auhind, Mart Remmel."

Siinkirjutaja lisab keeleauhinna nimevaliku võimalike või kaudsete mõjutajate nimekirja veel ühe isiku: Vaino Väljase. 1988. aasta juunis kutsuti Nõukogude Liidu suursaadik Nicaraguas Vaino Väljas kiiresti Moskvasse. Seal teatas NLKP Keskkomitee peasekretär Mihhail Gorbatšov, et Väljasel tuleb asuda Karl Vaino asemel Eestimaa Kommunistliku Partei (EKP) Keskkomitee I sekretäri ametikohale.

Siinkirjutaja mälupildi kohaselt 1988. aasta hilissügisel - aga inimmälu võib olla ekslik - küsis keegi Eesti Televisiooni ajakirjanikest kaamera ees Väljaselt, millist raamatut ta sel õhtul loeks. Küsitletav vastas umbes nõnda: „Täna sirviksin ma ehk Wiedemanni sõnaraamatut, imetleksin eesti keele väljendusrikkust ja ilu."

Laiema silmaringiga inimeste seas oli akadeemik F. J. Wiedemanni nimi tuntud, samuti oli tuntud tema eesti-saksa sõnaraamat (nt selle neljas trükk, 1973). Eesti filoloogia esmakursuslaste rebaseks löömine toimus sageli 
Wiedemanni sõnaraamatuga. ${ }^{3}$ Vaino Väljase abikaasa Mai Väljas oli eesti filoloog (vt Tender 2018).

Diplomaatlik Vaino Väljas tajus ühiskonna meeleolusid, mõistis eesti keele õppimise ja kasutamise tähtsust. ${ }^{4}$

Oletust Väljase võimaliku mõju kohta toetab veidi ehk seegi, et 1) oma seisukohtade väljendamisel toetuti toona veel marksismi-leninismi klassikute tsitaatidele ning parteijuhtide seisukohtadele. Miks siis mitte ka Väljase omadele, kuna ta oli uuendusmeelse parteijuhina eestlaste seas suhteliselt populaarne; 2) Rimmel jt keeleauhinna asutajad kohtusid kirjanike liidus EKP ideoloogiasekretäri Mikk Titmaga (vt eespool tsitaati Rimmeli kirjast 22. II 1989). Kindlasti oli ideoloogiasekretär kursis partei esimese sekretäri ehk oma ülemuse seisukohaga. Seega võis Väljase teleintervjuus öeldud lause auhinna nimevalikut mõjutada. Mõju võisid üheaegselt avaldada ka mitu isikut ning mitu sündmust. Kuid nagu eespool juba mööndud, lõplikku tõde me ei tea.

Eesti keele mainekal auhinnal on seega Ferdinand Johann Wiedemanni nimi $^{5}$ ja auhinna laureaate võib nimetada lühidalt Ferdinandi mantlipärijateks. Riiklikku keeleauhinda antakse välja igal aastal Eesti Vabariigi sünnipäeval. Väike-Maarjas peetakse kevadel Wiedemanni keeleauhinna päeva laureaat istutab sealsesse Keeletammikusse oma tamme ning peab ettekande. Mõneaastase sammuga on korraldatud rahvusvahelist konverentsi „Emakeelne Eesti, emakeelne Euroopa”, suulises kõnepruugis Wiedemanni konverentsi. Kaks esimest toimusid 2008. ja 2013. aastal Väike-Maarjas. Seni viimane, kolmas konverents peeti 2018. aastal Väike-Maarjas ja Rakveres. Kahel varasemal korral avaldati konverentsi ettekanded või nende lühikokkuvõtted raamatuna. Konverentsil „Emakeelne Eesti, emakeelne Euroopa III” kõlanud ettekannete valimik ilmub nüüd ajakirja Keel ja Kirjandus topeltnumbris. „Ferdinandi mantlipärijad” viitab nii akadeemik Wiedemanni ühele eesnimele, keeleauhinnale ja selle laureaatidele, Wiedemanni konverentsile kui ka seal ettekandeid pidanud inimestele.

Siinse, eesti keele aasta puhul välja antud teemanumbri artiklite rubriiki mahuvad nii keele- kui ka kirjandusvaldkonda kuuluvad kaastööd. Anna Verschik käsitleb mitmekeelsust ning tutvustab ja selgitab mitmekeelse teadlikkuse juhtumeid. Martin Ehala pakub välja praktilisi samme: mida ette võtta, millist poliitikat ajada olukorras, kus Eesti iive on negatiivne, kuid soovime majandusliku heaolu jätkumist ning eesti keele ja kultuuri kestmist.

${ }^{3}$ Pealae või õla puudutamine selle sõnaraamatuga pühitses esmakursuslase täieõiguslikuks üliõpilaseks. „Rebaseks löödi enamasti oktoobris-novembris ja igal teaduskonnal kujunesid välja oma kindlad rebasekslöömise paigad ja tavad. Filolooge löödi rebaseks näiteks F. J. Wiedemanni [---] sõnaraamatuga [---]" (Berta. Eesti rahvakalendri tähtpäevade andmebaas).

${ }_{4}$ Näiteks 1978. aasta venestamise ajal ei mõistnud NSV Liidu haridusminister M. Prokofjev, miks on eestikeelsete koolide keskastmes vaja eesti emakeelt õppida, ning pidas liiga suureks eesti kirjandustundide arvu. EKP Keskkomitee sekretär Vaino Väljas, kes pooldas eesti keele ja kirjanduse õpetamist, suutis selles veenda NSV Liidu Haridusministeeriumi Koolide Peavalitsuse juhatajat J. Ivanovi ning viimaks nõustus sellega ka M. Prokofjev (Nagel 2006: 120, viidatud Pilve 2013: 11 kaudu).

${ }^{5}$ 2018. aasta aprillis ajas Kanal 2 õhtuste uudiste lugeja segi kaks nime: F. J. Wiedemann ning Rein Veidemann. Kanali uudistes kõneldi Veidemanni konverentsist. Eksimine on inimlik. 
Mare Kitsnik analüüsib kogemustele toetudes keeleõppe tulemuslikkust. Keeleõppija areng on kiirem, kui ta asub kohe keelt kasutama. Selleks on vaja õppijad vabastada õppimisega seotud hirmudest ja stressist, sel juhul on neil julgust keelt aktiivsemalt kasutada ja õppimise motivatsioon kasvab.

Kristiina Ross näitab oma kirjakeele ajaloo teemalises artiklis, missuguseid inimrühmi on eesti keele oskamine ja arendamine varasemal ajal ühte sidunud ning millised olid kirjakeelte arendajate eesmärgid ja valikuvõimalused.

Heiki Pisuke keskendub tõlkimisele Euroopa Liidu institutsioonides. Autor on valdkonna kogenud praktik. Kirjutis tõstab esile tõlkimise ja tõlketööstuse kui eesti keele arendamise olulise tahu, tutvustab tõlkija elukutse muutumist ajas, sh tõlkemasinat, tõlkimise eripärasid ja keerukust.

Kaks kirjandusartiklit tuginevad samuti nende autorite pikaajalisele kogemusele. Cornelius Hasselblatt tutvustab mõne konkreetse näite põhjal Kreutzwaldi „Kalevipoeg”, Jaan Krossi „Keisri hull”, Andrus Kivirähki „Mees, kes teadis ussisõnu” ja Maarja Kangro „Klaaslaps” -, kuidas ning miks on eri keeltes-kultuurides eesti kirjandust vastu võetud. Guntars Godiñ̌s vahendab lugejale oma pikaajalist ning väärtuslikku tõlkijakogemust eesti keelest läti keelde. Ta on läti keelde tõlkinud eesti rahvaluulet ja nüüdisautoreid - luulet, proosat, lasteraamatuid, näidendeid.

Esseede ja lühikirjutistegi seas sisaldub mitu huvitavat teksti. Peeter Päll vaatleb keelekorralduse teisenemist sajandi jooksul. Wiedemanni keeleauhinna seni viimane laureaat Reet Kasik kirjutab kirjakeele tähtsusest ja väärtusest ning sellest, mis võiks tagada eesti keele kestmise ja arendamise tulevikuski. Heido Otsa kaastöö on siinses ajakirjas ainus, mis ei pärine Wiedemanni konverentsilt, vaid Tallinna Ülikooli korraldatud teaduskeele konverentsilt. Ots näitab, et suured arvud võivad eri keelest tõlkides tekitada eesti keeles suurt segadust.

Paavo Kivine kirjutab Eesti suurmees Georg Lurichist: meie moodsa spordi loojast ning rahvustunde äratajast. Ajakirjas sisaldub ka kolm keele ja kirjanduse suhteid uurivat arvustust: Tiit Hennoste vaatleb luuleantoloogiat „Keele maitsest”, Henrik Sova Tõnis Vilu luulekogu „Libavere” ning Külli Prillop Mihhail Lotmani ja Maria-Kristiina Lotmani monograafiat „Eesti silbilis-rõhulise rütmika jooni: neliktrohheus ja -jamb 19. sajandi teisel poolel ja 20. sajandi alguses".

\section{Kirjandus}

Berta. Eesti rahvakalendri tähtpäevade andmebaas. Rebaseks löömine (rebaste ristimine, rebaste retsimine, rebaste pidu, jukude pidu) - oktoober. http://www. folklore.ee/Berta/tahtpaev-rebased.php (20. I 2019).

$\mathrm{N}$ a gel, Veronika 2006. Hariduspoliitika ja üldhariduskorraldus Eestis aastatel 1940-1991. (Sotsiaalteaduste dissertatsioonid 22.) Tallinn: Tallinna Ülikooli Kirjastus.

Pilve, Eli 2013. Nõukogude noorte kasvatamisest paberil ja tegelikkuses. Ideoloogiline ajupesu Eesti NSV kooli(tunni)s 1953-1991. - Tuna, nr 3, lk 82-100; 
saadaval ka http:/www.mnemosyne.ee/old/wp-content/uploads/2014/04/Eli_ Pilve_-_Noukogude_noore_kasvatus.pdf, lk 1-19.

Ros s, Eevi (koost ja toim) 2005. F. J. Wiedemanni keeleauhind 1989-2003. Tallinn: Eesti Keele Sihtasutus.

R os s, Eevi 2008. F. J. Wiedemanni keeleauhind ja selle laureaadid. - Emakeelne Eesti, emakeelne Euroopa. Koost Urmas Sutrop, Jüri Valge. Tallinn: Eesti Keele Sihtasutus, lk 17-26.

Ross, Eevi 2013. Tagasi minevikku. - Ferdinand Johann Wiedemanni keeleauhind 25. Koost Jüri Valge. Tallinn: Eesti Keele Sihtasutus, lk 21-38.

Rätse p, Huno 2008. Akadeemik Ferdinand Johann Wiedemann ja eesti keel. Emakeelne Eesti, emakeelne Euroopa. Koost Urmas Sutrop, Jüri Valge. Tallinn: Eesti Keele Sihtasutus, lk 27-34.

Sild, Jüri, Sild, Irma 2013. Keeleauhind meie elus. - Ferdinand Johann Wiedemanni keeleauhind 25. Koost Jüri Valge. Tallinn: Eesti Keele Sihtasutus, lk 11-19.

Tender, Tõnu 2018. Maine asi. Eesti keele maine ja selle kujundamine. Ettekanne J. V. Veski päeval „Kuidas elad, eesti keel?” 27. VI 2018 TÜ peahoone J. V. Veski auditooriumis. 